\title{
Characterization of biochars produced from peanut hulls and pine wood with different pyrolysis conditions
}

\author{
James W. Lee ${ }^{1,4^{*}}$, Bob Hawkins², Michelle K. Kidder ${ }^{1}$, Barbara R. Evans ${ }^{1}$ A. C. Buchanan ${ }^{1}$ and Danny Day ${ }^{3}$
}

\begin{abstract}
Background: Application of modern biomass pyrolysis methods for production of biofuels and biochar is potentially a significant approach to enable global carbon capture and sequestration. To realize this potential, it is essential to develop methods that produce biochar with the characteristics needed for effective soil amendment.

Methods: Biochar materials were produced from peanut hulls and pine wood with different pyrolysis conditions, then characterized by cation exchange (CEC) capacity assays, nitrogen adsorption-desorption isotherm measurements, micro/nanostructural imaging, infrared spectra and elemental analyses.

Results: Under a standard assay condition of pH 8.5, the CEC values of the peanut hull-derived biochar materials, ranging from 6.22 to $66.56 \mathrm{cmol} \mathrm{kg}^{-1}$, are significantly higher than those of the southern yellow pine-derived biochar, which are near zero or negative. The biochar produced from peanut hulls with a steam activation process yielded the highest CEC value of $66.56 \mathrm{cmol} \mathrm{kg}^{-1}$, which is about 5 times higher than the cation exchange capacity $\left(12.51 \mathrm{cmol} \mathrm{kg}^{-1}\right)$ of a reference soil sample. Notably, biochar produced from peanut hulls with batch barrel retort pyrolysis also has a much higher CEC value $\left(60.12 \mathrm{cmol} \mathrm{kg}^{-1}\right)$ than that $\left(12.45 \mathrm{cmol} \mathrm{kg}^{-1}\right)$ from Eprida's $\mathrm{H}_{2}$-producing continuous steam injection process. The CEC values were shown to correlate well with the ratios of oxygen atoms to carbon atoms ( $\mathrm{O}: \mathrm{C}$ ratios) in the biochar materials. The higher $\mathrm{O}: \mathrm{C}$ ratio in a biochar material may indicate the presence of more hydroxyl, carboxylate, and carbonyl groups that contribute to a higher CEC value for the biochar product. In addition, the increase in surface area can also play a role in increasing the CEC value of biochar, as in the case of the steam activation char.
\end{abstract}

Conclusion: Comparison of characterization results indicated that CEC value is determined not only by the type of the source biomass materials but also by the pyrolysis conditions. Biochar with the desirable characteristics of extremely high surface area $\left(700 \mathrm{~m}^{2} / \mathrm{g}\right)$ and cation exchange capacity $(>60 \mathrm{cmol} \mathrm{kg})$ was created through steam activation.

Keywords: Biochar cation exchange capacity, Biochar surface areas, Biochar O:C ratios, Biomass pyrolysis, Biochar soil amendment, Carbon sequestration

\section{Background}

The world currently faces a systematic problem of increased $\mathrm{CO}_{2}$ emissions, decreased soil-carbon content, and global-climate change (global warming). To solve this massive global energy and environmental sustainability

\footnotetext{
*Correspondence: jwlee@odu.edu

${ }^{4}$ Department of Chemistry and Biochemistry, Old Dominion University, Physical Sciences Building 3100, 4402 Elkhorn Ave, Norfolk, VA 23259, USA Full list of author information is available at the end of the article
}

problem requires a comprehensive portfolio of $\mathrm{R}$ and $\mathrm{D}$ efforts with multiple energy technologies. Application of modern biomass pyrolysis methods for production of biofuels and biochar is potentially a significant approach to enable global carbon capture and sequestration at GtC scales (Day et al. 2005; Lee and Day 2013). Two of us (Day and Lee) co-initiated this technology concept with biochar as a soil amendment and carbon sequestration agent first in 2002 through a provisional US patent application

\section{Springer Open}


followed by a PCT application (Day and Lee 2004). Using biochar samples produced by Eprida, Inc. (Athens, GA) from peanut hulls and pine wood, we performed certain experimental studies of the biochar materials with an ammonia carbonation process, cation exchange capacity assays, and micro/nanostructural analysis at Oak Ridge National Laboratory (ORNL) (Lee et al. 2013, 2010). This biochar soil amendment approach has received some recognition worldwide (Day and Lee 2004; Marris 2006; Lehmann 2007), especially since certain biochar-related soil (including Terra preta) research results have also indicated the possibility of using biochar as a soil amendment for carbon sequestration (Gundale et al. 2007; Solomon et al. 2007; Lehmann et al. 2006; Downie et al. 2011; Lee et al. 2010). Since the first USA biochar scientific symposium held in 2004 in Athens, Georgia, that was organized by one of us (Day) (Energy with Agricultural Carbon Utilization Symposium 2004), biochar research has increasingly become a wide-spread global scientific effort (Novak and Busscher 2013; Srinivasan et al. 2015; Zhang et al. 2015; Zhao et al. 2015, 2014; Windeatt et al. 2014; Lehmannn and Joseph 2009; Bates 2010). Recently, biochar soil application has been discussed at the United Nations Framework Convention on Climate Change for possible consideration as a potential climate mitigation technology in accounting carbon credit (International Biochar Initiative), and a methodology for including biochar soil application as a carbon trading option has been reviewed by the American Carbon Registry (Koper et al. 2013). However, significantly more studies are needed before this approach can be considered for wide-spread commercial implementation (Novak et al. 2014; Baronti et al. 2014; Dai et al. 2013; Singh et al. 2015, 2014; Zhang et al. 2010; Blackwell et al. 2010; Spokas et al. 2010; Beesley et al. 2010; Topoliantz et al. 2005). In this paper, we report the results of a biochar characterization study performed at ORNL using biochar materials produced from peanut hulls and pine wood under various different pyrolysis conditions as part of the efforts to develop better biochar materials for potential application as a soil amendment and carbon sequestration agent.

\section{Methods}

\section{Biochar materials}

The biochar materials (listed in Table 1) including peanut hull biochar and Southern yellow pine biochar were produced by the biomass pyrolysis process at Eprida and shipped to ORNL for characterization. The peanut hull biochar was produced from pelletized peanut hulls manufactured by Birdsong in Blakely, GA. The Southern yellow pine biochar was produced from pelletized southern yellow pine manufactured by Southern Shavings Co, Cherryville, NC.

Biochar samples \#4, 5, 8, 9, and 10 (as listed in Table 1) were generated in Eprida's pilot scale biomass to hydrogen plant located at the University of Georgia's BioCoversion Center. Since this was a DOE sponsored project to demonstrate hydrogen from biomass, the equipment and all material produced were under conditions optimized for hydrogen production rather than biochar production $\left(\mathrm{H}_{2}\right.$ continuous process). The plant consisted of a pyrolysis unit and a fluidized bed catalytic steam reformer for the production of biochar and hydrogen-rich syngas. The pyrolysis unit consisted of a rotary feeder and a variable speed auger for conveying the feedstock through the reactor. The system was electrically heated and utilized steam as a heated sweep gas and reactant. It typically operated around $15 \mathrm{~kg} / \mathrm{h}$ biomass throughput with char yields averaging $29-30 \%$. The average residence time was 12-15 $\mathrm{min}$. The pilot plant has been described in greater detail previously (Das et al. 2009). For all sample production runs, the temperature, rotary feeder, and auger

\section{Table 1 Sample identification (ID) numbers and description: biochars and a control soil sample}

\begin{tabular}{|c|c|c|}
\hline Sample ID & Sample description & Biomass pyrolysis condition \\
\hline 4 & PNC-EP char; Source: peanut hull & Eprida $\mathrm{H} 2$ continuous process char-temp $481^{\circ} \mathrm{C}, 5.4$ psig \\
\hline 5 & PNC-M char; Source: peanut hull & Eprida $\mathrm{H} 2$ continuous process char-temp $475^{\circ} \mathrm{C}, 1.4$ psig \\
\hline 6 & PNC-B char; Source: peanut hull & Batch barrel retort pyrolysis (no temp control/monitoring) \\
\hline 8 & PIC-EP char; Source: southern yellow pine & Eprida $\mathrm{H} 2$ continuous process char-temp $465^{\circ} \mathrm{C}, 4.2$ psig \\
\hline 9 & PIC-M char; Source: southern yellow pine & Eprida $\mathrm{H} 2$ continuous process char-temp $474^{\circ} \mathrm{C}, 1.5$ psig \\
\hline 10 & PIC-NS char; Source: southern yellow pine & Eprida $\mathrm{H} 2$ continuous process no steam char-temp $485^{\circ} \mathrm{C}, 0.5$ psig \\
\hline 12 & "High" char; Source: peanut hull & Eprida cross draft process, no steam char-average temp $950^{\circ} \mathrm{C}$ \\
\hline 13 & "Active" char; Source: peanut hull & $\begin{array}{l}\text { Eprida cross-draft process } 500 \mathrm{C} \text { followed steam activation } 800^{\circ} \mathrm{C} \\
\text { Char }\end{array}$ \\
\hline 14 & "Med" char; Source: peanut hull & Eprida cross-draft process, no steam-average temp $600^{\circ} \mathrm{C}$ \\
\hline 15 & $\begin{array}{l}\text { Control soil sample: Milan soil from 0-15 cm deep } \\
\text { Source: CSiTE, Milan, TN }\end{array}$ & \\
\hline
\end{tabular}


speed set-points remained constant and unchanged. Temperatures and pressures listed in Table 1 are measured values, and variances between samples are due to changes in feedstock, sweep gas, and downstream equipment selection. Biochar samples 4 (PNC-EP char) and 8 (PIC-EP char) were produced while the pyrolysis vapors were sent to the catalytic steam reformer and converted to hydrogen-rich syngas. This caused slight restriction in the flow of vapors out of the pyrolysis reactor. Biochar samples 5 (PNC-M char) and 9 (PIC-M char) were run while the pyrolysis vapors were sent directly to flare with none of the vapors being diverted to the steam reforming section and no flow restriction on pyrolysis vapors resulting in lower reactor pressure than samples 4 and 8. Biochar sample 10 (PIC-NS char) was produced with vapors sent directly to flare as with samples 5 and 9; however, no steam was present as a carrier gas in the pyrolysis reactor. Nitrogen was present as required to protect the equipment sensors but it was not present in a quantity significant to be considered a carrier gas.

Biochar 6 (PNC-B char) was created by Eprida in a batch retort shown in Fig. 1, which consisted of a 35 gal steel drum reactor placed inside a 55 gal steel drum that was used as an outer shell. The reactor was filled with $100 \mathrm{~kg}$ of peanut hull pellets with a char yield of $23 \%$. The pyrolysis vapors were collected via a single exhaust pipe that ran through the center of the reactor and exited out

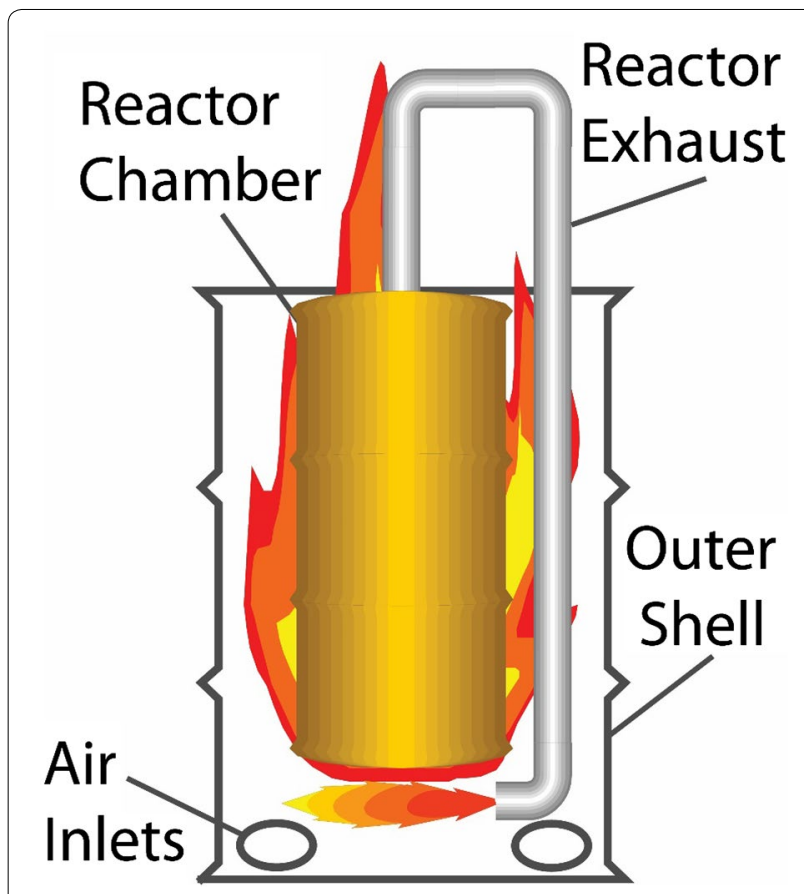

Fig. 1 Illustration of the barrel retort system that was used in producing biochar sample 6 from peanut hull the center top and were sent to the underside of the reactor inside the outer shell for combustion. The outer shell, wrapped with a blanket of ceramic insulation, had several $1^{\prime \prime}$ holes throughout the bottom to provide air flow. These holes could be individually blocked off by covering with mud. Peanut hulls were placed inside the 35-gal reactor that was sealed except for the exhaust pipe. Hardwood pallet scraps were placed in the bottom of the outer shell to provide the fuel to start the pyrolysis reaction. The pallet scraps were ignited and allowed to combust. The pyrolysis vapors eventually become the main fuel as the wood is consumed and the pyrolysis reaction intensifies. The heat from the combustion in the outer shell is used to provide the heat for pyrolysis inside the reactor. No temperature controls or monitoring equipment were present. The duration and residence time were not measured as the material was left to cool overnight. This method was used to represent low technology charcoal production that is employed throughout the world.

Biochar 12 ("High" char) was made from peanut hull with Day's custom designed cross draft thin bed pyrolysis reactor $(50 \mathrm{~kg} / \mathrm{h})$. It was designed to produce charcoal for steam activation in a second process. Rotary feed and discharge valves were used to control biomass flow. It utilized a natural gas burner operating at stoichiometric conditions to produce an inert gas stream that passed through a pyrolysis tube reactor with a diameter of $8 \mathrm{~cm}$ which also served as a moving bed of pelletized peanut hulls. The pressure was essentially atmospheric as gases where vented to a stack. Material exit temperature was used to control the biomass feed and discharge rates. The biochar of this sample was removed when it reached $950{ }^{\circ} \mathrm{C}$. This was an off-spec product but included for evaluation.

Biochar 13 ("Active" char) was made by Day from a biochar produced in a similar reactor as that which produced Biochar 12 and 14, but the exit temperature was approximately $500{ }^{\circ} \mathrm{C}$, and the biochar material was treated with steam in a novel three-zone 20 -ft-long rotary reactor at $800{ }^{\circ} \mathrm{C}$ via discharge ports built into the reactor shell on a $18-\mathrm{cm}$ square pattern for approximately $1 \mathrm{~h}$. The hydrogen and carbon monoxide produced by the reaction between the carbon and steam were burned above the bed by injection of air through the same ports to maintain the temperature with additional heat and steam derived from combustion of pyrolysis vapors. The feed rate was maintained at approximately $400 \mathrm{~kg} / \mathrm{h}$ and discharge rate was $200 \mathrm{~kg} / \mathrm{h}$. The material was cooled via a water jacket cooling transport cooler, then ground via a Williams Ring Roller Mill.

Biochar 14 ("Med" char) was made from the same process as that of biochar 12, except the temperature of the biochar when discharged was $600{ }^{\circ} \mathrm{C}$. This is typical of 
biochar designed for steam activation. This material was made as part of the DOE hydrogen program where the quantity of gas was more critical than impacts on the biochar. It was made at $600{ }^{\circ} \mathrm{C}$ in July 2002 as part of our 100 hour hydrogen production from biomass.

\section{Cation exchange capacity and its assay protocol}

A modified barium chloride compulsive exchange method (Skjemstad et al. 2008) was used in this study to determine the CEC for the biochar samples and a soil control from a standard test site located in West Tennessee as described above (University of Tennessee Research and Education Center, Milan, Tennessee, USA). The CEC value for the soil sample was reported previously (Lee et al. 2010). The detailed CEC protocol and data tables S1 and $\mathrm{S} 2$ are given in the Additional file 1 (supporting information). The test materials were ground for $4 \mathrm{~min}$ in a SPEX CertiPrep 8000-D Mixer mill with 1-cm (diameter) steel balls. Part of each ground sample was subsequently subjected to wet sieving with cutoff of $106 \mu \mathrm{m}$ followed by oven drying before the CEC assay (Additional file 1: Tables S2 and S3). All samples were assayed in duplicate at ambient temperature $\left(21-25{ }^{\circ} \mathrm{C}\right)$. Following the initial CEC determination for barium loading at $\mathrm{pH} 8.5$, the suspensions were adjusted to lower $\mathrm{pH}$ values by addition of $0.010 \mathrm{M} \mathrm{H}_{2} \mathrm{SO}_{4}$ and the $\mathrm{CEC}$ determined again. Milliequivalents of acid required for $\mathrm{pH}$ adjustment were determined by weighing the titration containers.

\section{Scanning electron microscopic (SEM) imaging}

SEM images were taken with a Hitachi S-4700 at the center for nanophase materials sciences (CNMS) at ORNL. Biochar samples were mixed in water or isopropyl alcohol (IPA) at $5 \mathrm{wt} \%$ then placed on top of a $500 \mu \mathrm{m}$ p-doped silicon wafer (which has very low resistance $<0.005 \Omega-\mathrm{cm}$ ) and dried to fix the biochar samples onto the wafer. A more detailed description of the biochar SEM imaging method and selected images at three magnifications of samples $4,5,6,8,9,12$, and 13 are presented as Additional file 1: Figures S1a, S1b, S1c, and S1d in the Supporting Information.

\section{Biochar surface area analysis}

Brunauer-Emmett-Teller (BET)-specific surface areas were obtained from nitrogen adsorption-desorption isotherms measured at $77 \mathrm{~K}$ on a Quantachrome Autosorb-1 analyzer with all samples outgassed at $200^{\circ} \mathrm{C}$ prior to analysis for a minimum of $8 \mathrm{~h}$. Pore size distributions were analyzed by the $\mathrm{BJH}$ method, and BET taken from a multipoint plot over a $\mathrm{P} / \mathrm{Po}$ range $0.05-0.35$. Isotherms from biochars 4, 5, 6, 8, 9, 12, and 13 are included in the Supporting Information file as Additional file 1: Figures S2, S3, S4, S5, S6, S7, and S8, respectively.

\section{Biochar infrared spectroscopic analysis}

Infrared spectra were recorded on a Digilab FTS 7000 FTIR spectrometer, collected in transmittance, resolution of $4 \mathrm{~cm}^{-1}$, 200 scans. Samples were prepared in KBr, 10 $\mathrm{wt} \%$, and pressed into a pellet. The spectra are presented in the Additional file 1, with Figure S9 showing the spectra for samples 4, 5, and 6; Additional file 1: Figure S10 those for 8 and 9; and Additional file 1: Figure S11 those for 12 and 13. Waveband assignments for functional groups are marked on the spectra in Additional file 1: Figure S11. Spectra shown are normalized at ca. $1827 \mathrm{~cm}^{-1}$.

\section{Elemental and proximate analysis}

Biochar samples were sent to Galbraith Laboratories, Knoxville, TN for elemental, and proximate analysis.

\section{Results and discussion}

\section{Cation exchange capacity (CEC) assay}

To test the accuracy of the conductivity assay method for low CEC values, four 20-ml aliquots of $0.010 \mathrm{M}$ $\mathrm{MgSO}_{4}$ were weighed and titrated to the conductivity of $0.0015 \mathrm{M} \mathrm{MgSO}_{4}$. Assuming a simulated sample size of $0.5 \mathrm{~g}$, an average value of $-2.750 \pm 0.2903 \mathrm{cmol} \mathrm{kg}^{-1}$ was obtained.

The observed cation exchange capacity of the biochars varied depending on the type of biomass and the pyrolytic treatment (Fig. 2; Additional file 1: Table S1 in the SI section). At the standard assay $\mathrm{pH}$ of 8.5 , the CEC values of the peanut hull-derived biochar materials (samples $4,5,6,12,13$, and 14) in a range from $6.22 \pm 0.64$ to $66.56 \pm 0.22 \mathrm{cmol} \mathrm{kg}^{-1}$ are significantly higher than those (near zero or negative CEC values) of the southern

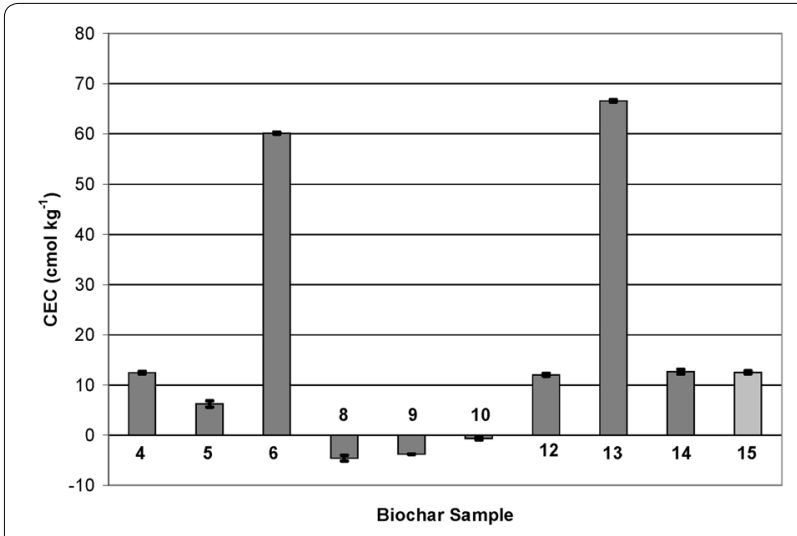

Fig. 2 Comparison of cation exchange capacities. The CEC values were determined in duplicate at the standard $\mathrm{pH}$ of 8.5 for the nine different agricultural chars and a soil control (\#15). A wide variation is observed for the averaged values dependent on source materials and char preparation methods. Error bars are standard deviations for each sample's averaged CEC assays (see Additional file 1: Table S1 in the Additional file 1) 
yellow pine-derived biochars (samples 8,9 , and 10). The PNC-EP biochar (sample 4) produced from the peanut hull through Eprida's continuous steam-injected charmaking process $\left(481{ }^{\circ} \mathrm{C}, 5.4 \mathrm{psig}\right)$ yielded a CEC value of $12.45 \pm 0.17 \mathrm{cmol} \mathrm{kg}^{-1}$, which is similar to that of a standard soil (sample 15). The PNC-M biochar (sample 5) produced from the peanut hull through Eprida's continuous steam-injected char-making process $\left(475{ }^{\circ} \mathrm{C}, 1.4\right.$ psig) resulted in a CEC value of $6.22 \pm 0.64 \mathrm{cmol} \mathrm{kg}^{-1}$. This result indicates that the pyrolysis condition of PNCEP $\left(481{ }^{\circ} \mathrm{C}\right.$, $\left.5.4 \mathrm{psig}\right)$ can produce biochar with a higher $\mathrm{CEC}$ value than that of $\mathrm{PNC}-\mathrm{M}\left(475^{\circ} \mathrm{C}, 1.4 \mathrm{psig}\right)$. This improvement in CEC value is probably owning to a higher steam-gas pressure (5.4 psig) used in the PNC-EP process than that (1.4 psig) of PNC-M.

Samples 6 (PNC-B char) and 13 ("Active" char), two of the peanut hull-derived biochar materials, were identified as some of the best biochar materials with the highest CEC values of $60.12 \pm 0.19$ and $66.56 \pm 0.22 \mathrm{cmol}$ $\mathrm{kg}^{-1}$, which is about five times higher than the cation exchange capacity $\left(12.51 \pm 0.30 \mathrm{cmol} \mathrm{kg}^{-1}\right)$ of a standard soil (sample 16, Milan top soil). The biochar of sample 6 (PNC-B char) was produced from peanut hull using a batch barrel pyrolysis technique mimicking a traditional char-making process without temperature control/ monitoring. The biochar of sample 13 ("Active" char) was produced from the peanut hull with a continuous active char-making process, which resulted in an CEC value of $66.56 \pm 0.22 \mathrm{cmol} \mathrm{kg}^{-1}$. Surprisingly, the PNC-B biochar produced from a batch barrel retort pyrolysis of peanut hull also has much higher CEC value $(60.12 \pm 0.19 \mathrm{cmol}$ $\mathrm{kg}^{-1}$ ) than that of the PNC-EP biochar from Eprida's $\mathrm{H}_{2}$-producing continuous steam-injected char-making process $\left(12.45 \pm 0.26 \mathrm{cmol} \mathrm{kg}^{-1}\right)$. These results indicate that CEC value is determined not only by the type of the source biomass materials but also by the pyrolysis conditions. The CEC value of sample 14 ("medium" char) which was produced by a heat treatment without steam of peanut hulls similar to sample 12, but at a lower temperature $\left(600{ }^{\circ} \mathrm{C}\right.$ instead of $\left.950{ }^{\circ} \mathrm{C}\right)$, was close to that of 12. This confirms the presence of steam during the treatment is one of the important process conditions to obtain the high CEC values observed in samples 6 and 13 .

Negative CEC values (such as $-4.582 \pm 0.563$, $-3.78 \pm 0.05$, and $-0.68 \pm 0.26 \mathrm{cmol} \mathrm{kg}^{-1}$ ) were observed for biochar samples 8 (PIC-EP char), 9 (PIC-M char), and 10 (PIC-NS char) that were produced from pyrolysis of southern yellow pine, and the CEC values generally became more negative for the CEC determination at $\mathrm{pH}$ values less than seven (Figs. 2, 3, 4). The $\mathrm{pH}$ curves for the CEC show that the chars have ion exchange characteristics similar to those observed for humic substances. Acidification appears to result in release of
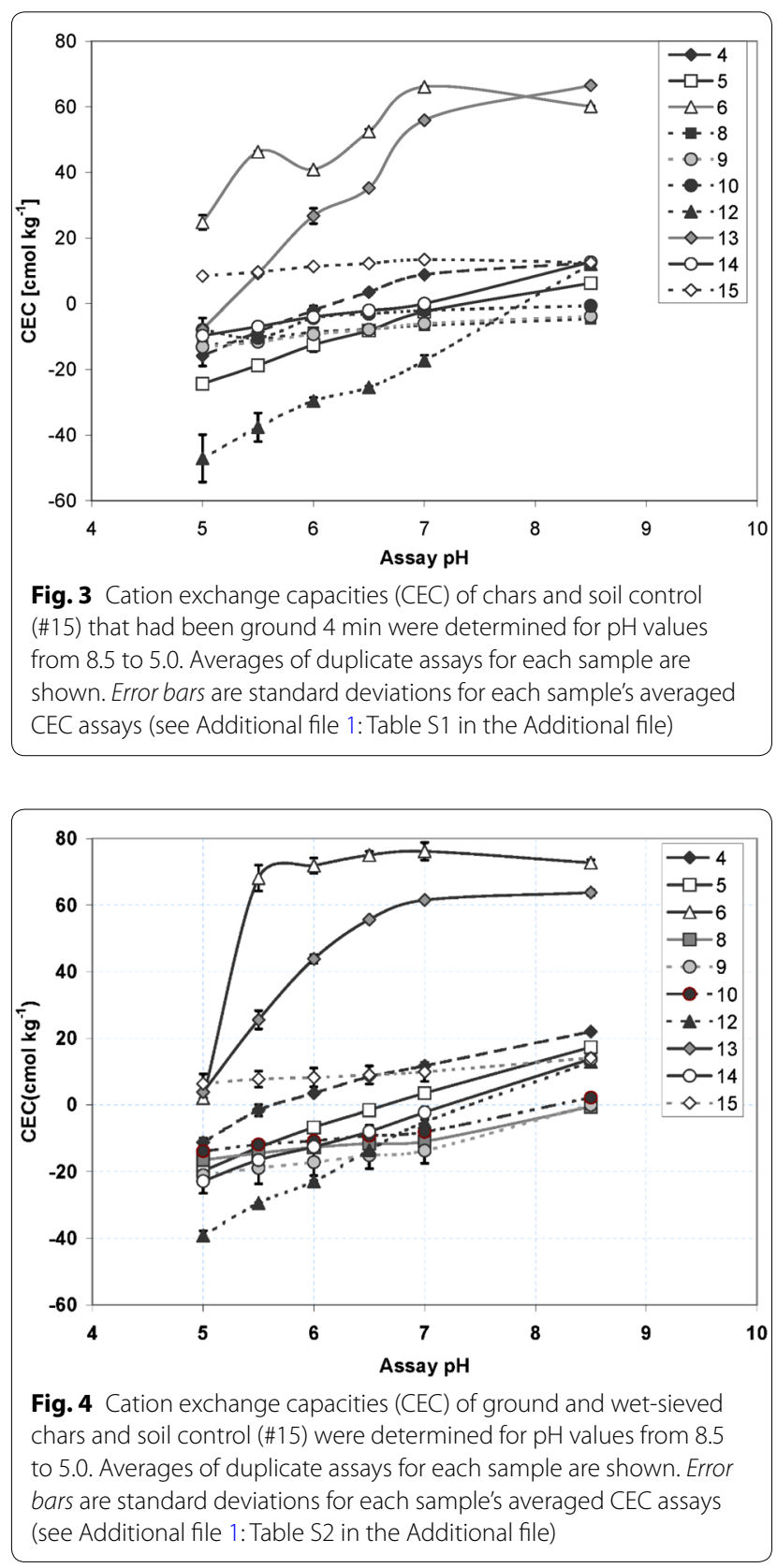

bound cations, probably $\mathrm{Ca}^{2+}$, at $\mathrm{pH}$ values lower than seven, resulting in negative CEC values. Similar results due to the presence of $\mathrm{Ca}^{2+}$ bound to soil organic matter have been reported (Skjemstad et al. 2008). The probable cause of the negative values is the inability of the barium to displace all of the bound cations during the loading at $\mathrm{pH}$ 8.5. The char samples may have low binding affinity for $\mathrm{Mg}^{2+}$ similar to that reported for humic substances (Manahan 1999), which may also influence the CEC determination by barium chloride-magnesium sulfate displacement. The biochar samples required the addition 
of much larger amounts of sulfuric acid to adjust the $\mathrm{pH}$ than did the soil control, suggesting that these materials possess an intrinsic buffering capacity. Results obtained from structural determinations of pyrolysis oils derived from biomass indicate that the lignin residues survive pyrolysis largely intact (Fratini et al. 2006), implying that biochars are primarily composed of lignin residues and that their soil amendment benefits stem from chemical properties resembling those of humus composed of lignin residues from biomass degradation.

The CEC values were determined for the wet-sieved biochar and soil samples (Additional file 1: Table S2). The effect of the wet-sieved treatment on the CEC varied dependent on the sample. The CEC values obtained were similar to those before sieving for chars $4,5,6$, and 13, but decreased two-fold or greater for chars $8,9,10$, 12,14 , and soil control 15 . The recovery of the char samples and soil control from the wet-sieving procedure was determined by drying and weighing the sieved particles with size less than $106 \mu \mathrm{m}$ and the residue greater than $106 \mu \mathrm{m}$ remaining on the sieve (Additional file 1: Table S3). Statistical analysis was carried out with Student's $t$ test on the yields obtained by sieving to determine if the proportions of the chars that were smaller in size than $106 \mu \mathrm{m}$ were correlated with feedstock type, process temperature, steam activation, or high CEC values. Of these, only the feedstock type gave a $P$ value $<0.05$, with the yield of particles less than $106 \mu \mathrm{m}$ significantly higher for pine chars compared to peanut chars (see legend of Additional file 1: Table S3 for details of analysis). No correlation between the amount of material lost during sieving due to particle size greater in size than $106 \mu \mathrm{m}$ following grinding and the CEC values following sieving was apparent. The range of CEC values that were obtained for the char samples and the soil control is similar to but wider than that obtained for the archeological black carbon char samples and adjacent soils (Liang et al. 2006) when the CEC values reported here are converted to $\mathrm{mmol} \mathrm{kg} \mathrm{kg}^{-1}$ to correspond to the units used for the archeological samples. The range of CEC values that they reported ranged from 26 to $222 \mathrm{mmol} \mathrm{kg}{ }^{-1}$, corresponding to $2.6-22.2 \mathrm{cmol} \mathrm{kg}^{-1}$. They found that the higher CEC values corresponded to higher content of black carbon and higher content of soil nutrients. The results reported here for the CEC values of several modern biochars and a soil control range from -0.5 to $72 \mathrm{cmol} \mathrm{kg}^{-1}$. It is apparent from these results that both the biomass feed stock and the process conditions used to produce a biochar material determine the resultant CEC. This information assists the evaluation of the possible biochar processes for utility in production of soil amendments and carbon sequestration.
As shown in Additional file 1: Table S4, the statistical significance of the differences between the CEC values for the feed stocks and processes (Additional file 1: Table S2) was evaluated using Student's $t$ Test with Microsoft Excel 2010 software. The significance of the changes in CEC values for ground samples compared to ground and wet sieved with $106 \mu \mathrm{m}$ cutoff was also evaluated by calculation of $P$ values using Student's $t$ Test (Additional file 1: Table S5).

\section{FTIR results}

In Additional file 1: Figures S9 and S10, it is seen that samples 4, 5, and 6 of the Eprida peanut hull carry many distinct characteristic $\mathrm{OH}$ and $\mathrm{C}=\mathrm{O}$ frequencies (Socrates 1980), as does samples 8 and 9 of the southern yellow pine. In Additional file 1: Figure S11, the FTIR of samples 12 and 13 show loss of the characteristic $\mathrm{OH}$ $\left(3500 \mathrm{~cm}^{-1}\right)$ and $\mathrm{CH}$ peaks (several peak intensities missing between $1700-800 \mathrm{~cm}^{-1}$ ).

\section{Galbraith analysis results}

Overall, all biochars (samples 4, 5, 6, 8, 9, 12, and 13) produced from the peanut hull and southern yellow pine samples have relatively similar ash content of 4.5-14.6\%, carbon content of $73 \%$ (samples 4-6, 8-9, and 12-13), and oxygen atom content of 12-20\% (samples 4-6, 8-9 and 13), with exception of sample 12 at $7.5 \%$ ), see Table 2. It is also notable that the biochars of southern yellow pine have very little nitrogen $<0.5 \%$, whereas the peanut hull-derived biochars have $0.5-2.0 \%$ nitrogen.

Comparison of samples $\mathbf{4 , 5}$, and $\mathbf{6}$ show that there is a higher $\mathrm{O}: \mathrm{C}$ ratio for $\mathbf{6}$. FTIR analysis also shows that there is also qualitatively stronger $\mathrm{C}=\mathrm{O}$ and $\mathrm{OH}$ absorbance than that of 5 . It is also interesting to note that the CEC value for 6 is significantly larger $\left(60.1 \mathrm{cmol} \mathrm{kg}^{-1}\right)$, than for 4 and $\mathbf{5}\left(12.4\right.$, and $6.2 \mathrm{cmol} \mathrm{kg}^{-1}$, respectively).

Samples 12 and 13 show similar ash content. Sample 13 has a slightly higher \% volatile matter ( $8.86 \%$ vs. 6.15$)$ than 12, but a lower calculated fixed carbon (67.8 vs. 75.1). However, despite that the \%C of $\mathbf{1 2}$ and $\mathbf{1 3}$ are very similar, $\mathbf{1 3}$ has a significant amount of more \% $\mathrm{O}$, which calculates to a factor of 1.7 times higher $\mathrm{O}: \mathrm{C}$ ratio for $\mathbf{1 3}$ than 12. This correlates again with the CEC ratio, where 13 has a significantly higher CEC of $66.6 \mathrm{cmol} \mathrm{kg}^{-1}$ and sample $12 \mathrm{ca} .12 .0 \mathrm{cmol} \mathrm{kg}^{-1}$. In addition, sample 13 has a larger surface area, ca. 3.3 times that of 12 , see below.

Samples 8 and 9, southern yellow pine, have similar values in all the elemental and proximate analyses, with only the \% ash being slightly higher for $\mathbf{8}$, but the resultant $\mathrm{O}: \mathrm{C}$ ratios for both samples are $0.15: 1$. It is notable that the CEC values for $\mathbf{8}$ and $\mathbf{9}$ are similar, with negative CEC values of ca. -4.7 to -3.8 . 
Table 2 Elemental and proximate analysis of biochars was carried out by Galbraith Laboratories, Knoxville, TN

\begin{tabular}{|c|c|c|c|c|c|c|c|c|c|c|}
\hline Sample ID & $\begin{array}{l}\text { \% Loss } \\
\text { on drying }\end{array}$ & $\begin{array}{l}\text { \% Volatile } \\
\text { matter } \\
\text { @950 }{ }^{\circ} \mathrm{C}\end{array}$ & $\%$ Ash & $\begin{array}{l}\text { \% Fixed } \\
\text { carbon (by } \\
\text { difference) }\end{array}$ & $\begin{array}{l}\text { C \% } \\
\text { (mol \%) }\end{array}$ & $\begin{array}{l}\mathrm{H} \% \\
\text { (mol \%) }\end{array}$ & $\begin{array}{l}\% \mathrm{~N} \\
\text { (mol \%) }\end{array}$ & $\begin{array}{l}\text { O \% } \\
\text { (mol \%) }\end{array}$ & $\begin{array}{l}\text { S \% } \\
\text { (mol \%) }\end{array}$ & $\begin{array}{l}\mathrm{O}: \mathrm{C} \text { (mol } \\
\text { ratio) }\end{array}$ \\
\hline$\# 4$ & 5.86 & 23.13 & 7.57 & 65.54 & $71.54(0.060)$ & $2.90(0.03)$ & 2.08 & $16.59(0.010)$ & 0.106 & $0.167: 1$ \\
\hline$\# 5$ & 6.30 & 22.25 & 7.51 & 67.08 & $72.33(0.060)$ & $2.80(0.028)$ & 1.92 & $15.00(0.0094)$ & 0.108 & $0.156: 1$ \\
\hline$\# 6$ & 13.31 & 25.78 & 7.16 & 60.41 & $68.26(0.057)$ & $2.76(0.028)$ & 1.97 & $19.88(0.012)$ & 660 ppm & $0.218: 1$ \\
\hline \#8 & 4.54 & 22.60 & 7.54 & 67.60 & $74.78(0.062)$ & 3.19 & $<0.5$ & 14.99 (0.0094) & $<0.09$ & $0.151: 1$ \\
\hline$\# 9$ & 5.37 & 22.55 & 4.50 & 70.27 & 76.59 (0.0638) & 2.97 & $<0.5$ & $15.42(0.0096)$ & $<0.08$ & $0.151: 1$ \\
\hline$\# 12$ & 8.14 & 6.15 & 14.66 & 75.12 & $74.94(0.062)$ & $0.84(0.084)$ & 0.95 & $7.45(0.0047)$ & 0.16 & $0.075: 1$ \\
\hline \#13 & 19.58 & 8.86 & 13.60 & 67.76 & $72.68(0.061)$ & $0.71(0.071)$ & 0.53 & 12.61 (0.0079) & 0.17 & $0.129: 1$ \\
\hline
\end{tabular}

Analysis results are the average of two analyses per sample expressed as \% dry weight, except for the percent loss on drying, which is based on a one-time analysis. Standard deviations were $<10 \%$ (values given in parentheses)

Table 3 BET measurements of biochar samples

\begin{tabular}{ll}
\hline Sample ID & $\begin{array}{l}\text { Surface area } \\
\text { (multipoint BET): } \mathbf{~ m}^{\mathbf{2}} \mathbf{g}\end{array}$ \\
\hline$\# 4$ & 2.52 \\
$\# 5$ & 15.15 \\
$\# 6$ & 7.70 \\
$\# 8$ & 4.64 \\
$\# 9$ & 186 \\
$\# 12$ & 210.3 \\
$\# 13$ & 697.4 \\
\hline
\end{tabular}

\section{Surface analysis}

For BET analysis, Table 3 and Additional file 1: Figures $\mathrm{S} 2-\mathrm{S} 8$, all samples were outgassed a minimum of $8 \mathrm{~h}$ at $200{ }^{\circ} \mathrm{C}$. In general, the isotherms look like Type I, which indicates microporous solids having relatively small external surfaces, for all samples excluding 9, 12, and 13, surface areas were between 4 and $57 \mathrm{~m}^{2} / \mathrm{g}$ for ground samples. The limiting uptake of adsorbate is governed by the accessible micropore volume rather than the internal surface area. However, there is some hysteresis, in samples which indicates bottle-neck or slit-shaped pores, and in some cases, the desorption branch closes at very low $\mathrm{P} / \mathrm{Po}$, but sometimes it does not, which is probably an effect of the micropores unable to desorb the $\mathrm{N}_{2}$ at high pressure. Also, there is no distinct curvature at lowrelative pressure $(\mathrm{P} / \mathrm{Po})$, or central linear section of the isotherm, which indicates a strong adsorbate-adsorbate $\left(\mathrm{N}_{2}-\mathrm{N}_{2}\right.$ gas) interaction rather than adsorbate-adsorbent $\left(\mathrm{N}_{2}\right.$-substrate). All of the isotherms except 13 do not close before reaching a relative pressure of $<0.3$ in the desorption process indicating that microporosity is present. Surprisingly, 12 and 13 have very large surface areas, and 13 exhibits a near closed loop hysteresis above $0.3 \mathrm{P} / \mathrm{Po}$, indicating possible "ink bottle" pores, but pore analysis indicates that the micropores are $<1.5 \mathrm{~nm}$ in diameter.

\section{SEM imaging analysis}

The SEM images of biochar samples 4, 5, 6, 8, 9, 12, and 13 were presented in Additional file 1: Figures S1a-S1d. From left to the right, magnification is 5, 50, and 500K. For each biochar sample, SEM images of three randomly selected spots were presented. According to the SEM images, samples 12 and 13 appear containing more porous or "sponge" type of micro/nanometer structures than samples $4,5,6,8$, and 9. This observation seems consistent with the results of the BET analysis, where biochar samples 12 and 13 showed very large surface areas as reported above.

Relationship among biochar cation exchange capacity, O:C ratio, and surface area

When the cation exchange capacities (CEC) measured at $\mathrm{pH} 8.5$ were plotted as a function of the O:C ratio in biochar materials (Fig. 5, top), we noticed a quite clear relationship with the two. As the atomistic O:C ratio increases to above 0.15 , biochar cation exchange capacity appears to rise dramatically although there are outliers.

One of the outliers is the cation exchange capacity value of $63.78 \mathrm{cmol} \mathrm{kg}^{-1}$ with an O:C ratio of 0.129 from sample \#13 which is the "active" char that was produced from peanut hull through the Eprida Cross-Draft Process at $500{ }^{\circ} \mathrm{C}$ followed by an $800{ }^{\circ} \mathrm{C}$ steam activation. As shown in Fig. 5 (bottom), this steam-activated biochar has much larger surface area (about $700 \mathrm{~m}^{2} / \mathrm{g}$ ) than any of the other biochars. This explains why its cation exchange capacity is so high (63.78 $\left.\mathrm{cmol} \mathrm{kg}^{-1}\right)$; apparently because CEC in some extent is also dependent on biochar surface area.

When biochar BET surface area was plotted against the $\mathrm{O}: \mathrm{C}$ ratio (Fig. 5, bottom), we noticed, these two properties seem somewhat inversely related. As the atomistic $\mathrm{O}: \mathrm{C}$ ratio decreases, biochar BET surface area has a trend to increase. This observation is consistent with the understanding that the low $\mathrm{O}: \mathrm{C}$ ratio (such as 0.075 in biochar 


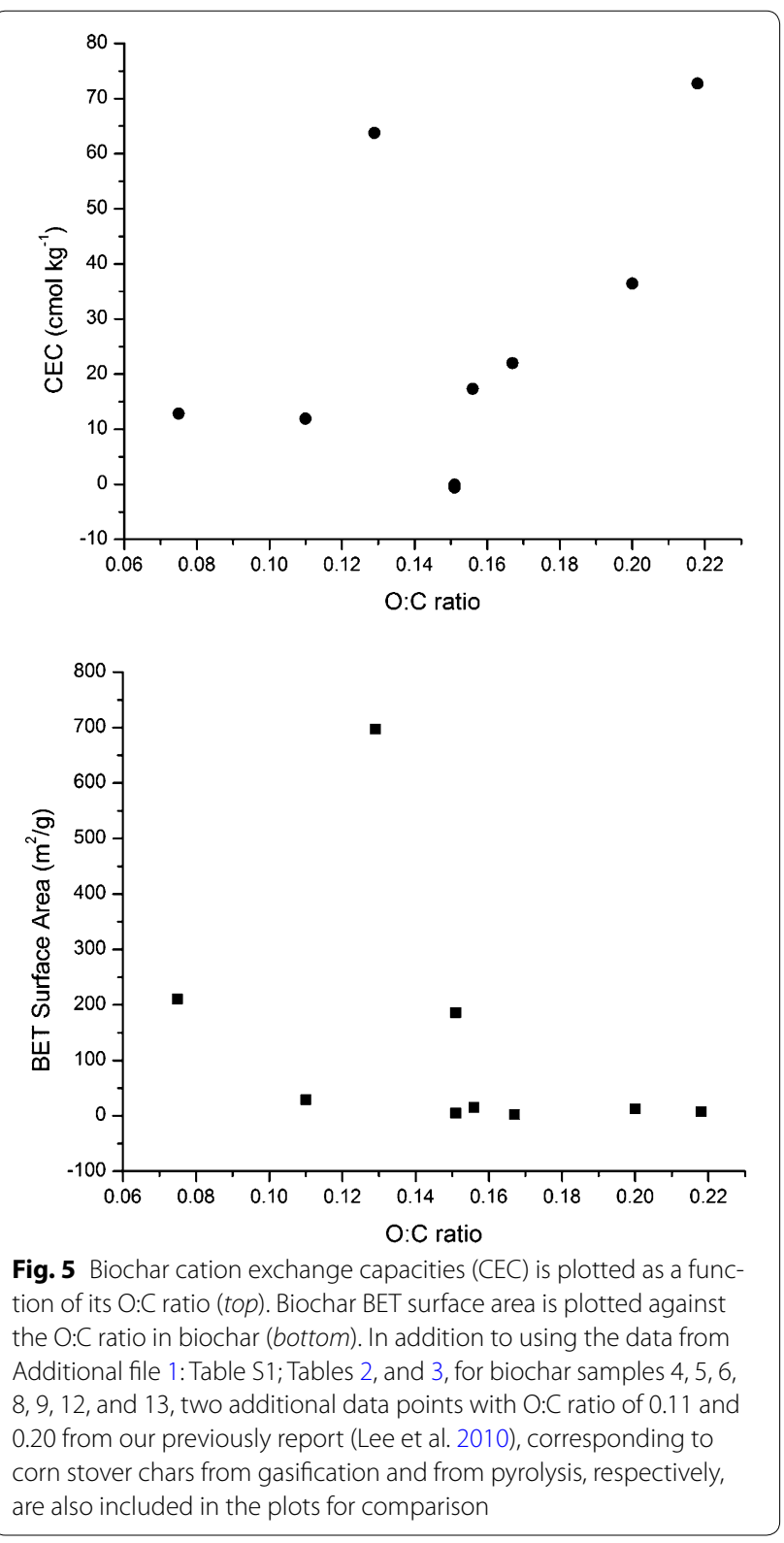

sample \#12) was likely resulted from a high pyrolysis temperature (e.g., $950{ }^{\circ} \mathrm{C}$ ) that favors deoxygenation and gasification of biomass, producing a biochar with somewhat higher surface area (Jindo et al. 2014; Budai et al. 2014; Wang et al. 2013). However, a moderate increase in biochar surface area under this condition apparently does not overweigh (overbalance) the loss of oxygen-containing functional groups due to the thermal deoxygenation of biochar products. Except in the case of steam activation, use of a moderate biomass pyrolysis temperature and/or condition that can retain a relatively higher $\mathrm{O}: \mathrm{C}$ ratio is more likely to produce a desirable biochar with a higher cation exchange capacity. A similar relationship (trend) between $\mathrm{O}: \mathrm{C}$ ratio and cation exchange capacity was recently noticed also in a separate study with biochars from a hydrothermal biomass conversion process (Huff et al. 2014).

\section{Summary}

Under a standard assay condition of $\mathrm{pH} 8.5$, the CEC values of the peanut hull-derived biochar materials (samples $4,5,6,12,13$, and 14) in a range from $6.22 \pm 0.64$ to $66.56 \pm 0.22 \mathrm{cmol} \mathrm{kg}^{-1}$ are significantly higher than those (near zero or negative CEC values) of the southern yellow pine-derived biochars (samples 8, 9, and 10). The biochar (sample 4) produced from the peanut hull through a continuous steam-gasified biochar-making process yielded a CEC value of $12.45 \pm 0.17 \mathrm{cmol}$ $\mathrm{kg}^{-1}$, which is similar to that of a standard soil (sample 15). The biochar (sample 5) produced from the peanut hull through Eprida's $\mathrm{H}_{2}$ continuous feed steam injection biochar-making process resulted in a CEC value of $6.22 \pm 0.64 \mathrm{cmol} \mathrm{kg}^{-1}$. Samples 6 and 13, two of the peanut hull-derived biochar materials, were identified as some of the best biochar materials with the highest CEC values of $60.12 \pm 0.19$ and $66.56 \pm 0.22 \mathrm{cmol} \mathrm{kg}^{-1}$, which is about five times higher than the cation exchange capacity $\left(12.51 \pm 0.30 \mathrm{cmol} \mathrm{kg}^{-1}\right)$ of a standard soil (sample 15, Milan top soil). The biochar of sample 6 (PNC-B char) was produced from the peanut hull using a batch barrel slow pyrolysis technique mimicking a traditional char-making process without temperature control/monitoring. The biochar of sample 13 ("Active" char) was produced from the peanut hull with a continuous active char-making process, which resulted in an CEC value of $66.56 \pm 0.22 \mathrm{cmol} \mathrm{kg}^{-1}$. Surprisingly, the PNC-B biochar produced from a batch barrel retort pyrolysis of peanut hull has much a higher CEC value $(60.12 \pm 0.19 \mathrm{cmol}$ $\left.\mathrm{kg}^{-1}\right)$ than that $\left(12.45 \pm 0.17 \mathrm{cmol} \mathrm{kg}^{-1}\right)$ of the PNC-EP biochar from Eprida's $\mathrm{H}_{2}$-producing continuous steaminjected char-making process.

These results indicate that CEC value is determined not only by the type of the source biomass materials but also by the pyrolysis conditions. It was also found that the CEC values correlate well with the ratios of the oxygen atoms to the carbon atoms (O:C ratios) in the biochar materials. That is, the higher the $\mathrm{O}: \mathrm{C}$, the higher the CEC value. The higher $\mathrm{O}: \mathrm{C}$ ratio in a biochar material may indicate the presence of more hydroxyl, carboxylate, and carbonyl groups that could contribute to a higher CEC value for the biochar product. In addition, the increase in surface area can also play a role in the increased CEC value of biochar. Although sample 13 ("Active" char) has a smaller O:C ratio than biochar 6 (PNC-B), the increase in surface area apparently also plays a role in increasing its CEC value. 


\section{Additional file}

Additional file 1. Supporting information for this article is available online at the journal website. The supporting information describes: (1) Reference Soil Sample; (2) Detailed protocol for biochar sample grinding, sieving, and cation exchange capacity (CEC) determination and includes CEC data tables, calculation equations, and statistical analysis of CEC results; (3) Detailed description of scanning electron microscopic (SEM) sample preparation and imaging procedures; (4) Nitrogen adsorptiondesorption isotherms from biochar surface area (BET) analysis; (5) Fourier transform infrared spectroscopy (FTIR) of biochar materials.

\section{Authors' contributions}

JWL conducted the overall biochar research project, analyzed data, and drafted the manuscript. $\mathrm{BH}$ and DD conducted the biochar production processes and co-wrote the description of biochar product samples and their associated production processes. BRE carried out CEC assays, biochar wet sieving, and statistical analysis and co-wrote the manuscript. MKK and ACB conducted the biochar elemental analysis, BET and FTIR measurements and co-wrote the manuscript. All authors read and approved the final manuscript.

\section{Author details}

1 Oak Ridge National Laboratory, P.O. Box 2008, Oak Ridge, TN 37831, USA

2 BiocharConsulting, 375 Rumson Rd, Athens, GA 30605, USA. ${ }^{3}$ Eprida Technologies, LLC, 4374 Shallowford Industrial Parkway, Marietta, GA 30066, USA. ${ }^{4}$ Department of Chemistry and Biochemistry, Old Dominion University, Physical Sciences Building 3100, 4402 Elkhorn Ave, Norfolk, VA 23259, USA.

\section{Acknowledgements}

The authors wish to thank Sokwon Paik for SEM imaging of biochars; Charles T. Garten, Deanne J. Brice, and Tanya Bunch for their assistance in helping the measurement of cation exchange capacity; and Mac Post and Joe Katz for stimulating discussions. This research was sponsored by the Laboratory Directed Research and Development Program of Oak Ridge National Laboratory, managed by UT-Battelle, LLC, for the US Department of Energy, by the US Department of Energy (DOE) Office of Science Young Scientist Award, by the US Presidential Early Career Award for Scientists and Engineers (to J. W. Lee), and by USDA Grant No. 68-3A75-5-233. Part of this research was conducted at the Center for Nanophase Materials Sciences, which is a DOE Office of Science User Facility. Oak Ridge National Laboratory is managed by UT-Battelle, LLC, for DOE under contract No. DE-AC05-00OR22725.

A. C. Buchanan: Currently retired at Oak Ridge National Laboratory.

\section{Competing interests}

The authors declare that they have no competing interests.

Received: 8 December 2015 Accepted: 6 March 2016

Published online: 22 March 2016

\section{References}

Baronti S, Vaccaria FP, Miglietta F, Calzolari C, Lugato E, Orlandini S, Zulian Pini CR, Genesio L (2014) Impact of biochar application on plant water relations in Vitis vinifera (L.). Eur J Agron 53:38-44

Bates A 2010) The Biochar solution: carbon farming and climate change (Sustainable Agriculture). New Society Publishers, Vancouver, p 208

Beesley L, Moreno-Jiménez E, Gomez-Eyles JL (2010) Effects of biochar and greenwaste compost amendments on mobility, bioavailability and toxicity of inorganic and organic contaminants in a multi-element polluted soil. Environ Pollut 158:2282-2287

Blackwell P, Krull E, Butler G, Herbert A, Solaiman Z (2010) Effect of banded biochar on dryland wheat production and fertiliser use in south-western Australia: an agronomic and economic perspective. Soil Res 48:531-545

Budai A, Wang L, Gronli M, Strand LT, Antal MJ Jr, Abiven S, Dieguez-Alonso A, Anca-Couce A, Rasse DP (2014) Surface properties and chemical composition of corncob and Miscanthus biochars: effects of production temperature and method. J Agric Food Chem 62(17):3791-3799

Dai Z, Meng J, Muhammad N, Liu X, Wang H, He Y, Brookes PC, Xu J (2013) The potential feasibility for soil improvement, based on the properties of biochars pyrolyzed from different feedstocks. J Soils Sediments 13:989-1000

Das KC, Singh K, Adolphson R, Hawkins B, Oglesby R, Lakly D, Day D (2009) Steam pyrolysis and catalytic steam reforming for hydrogen and biochar production. Appl Eng Agric 26(1):137-146

Day DM, Lee JW (2004) The production and use of a soil amendment made by the combined production of hydrogen, sequestered carbon and utilizing off gases containing carbon dioxide. PCT Int Appl 58:WO2004037747 A2

Day DM, Evans RJ, Lee JW, Reicosky D (2005) Economical CO2, SOx, and NOx capture from fossil-fuel utilization with combined renewable hydrogen production and large-scale carbon sequestration. Energy 30:2558-2579

Downie AE, van Zwieten L, Smernik RJ, Morris S, Munroe PR (2011) Terra Preta Australis: reassessing the carbon storage capacity of temperate soils. Agric Ecosyst Environ 140:137-147

Energy with Agricultural Carbon Utilization Symposium, held on June 10-11 2004, Athens

Fratini E, Bonini M, Oasmaa A, Solantausta Y, Teixeira J, Balioni P (2006) SANS analysis of the microstructural evolution during the aging of pyrolysis oils from biomass. Langmuir 22:306-312

Gundale MJ, Thomas H, DeLuca TH (2007) Charcoal effects on soil solution chemistry and growth of Koeleria macrantha in the ponderosa pine/ douglas fir ecosystem. Biol Fertil Soils 43:303-311

Huff MD, Kumar S, Lee JW (2014) Comparative analysis of pinewood, peanut shell, and bamboo biomass derived biochars produced via hydrothermal conversion and pyrolysis. J Environ Manage 146:303-308

Jindo K, Mizumoto H, Sawada Y, Sanchez-Monedero MA, Sonoki T (2014) Physical and chemical characterization of biochars derived from different agricultural residues. Biogeosciences 11:6613-6621

Koper T, Weisberg P, Lennie A, Driver K, Simons H, Rodriguez M, Reed D, Jirka S Gaunt J (2013) Methodology for biochar projects, American Carbon Registry [Online]. americancarbonregistry.org/C-accounting/ biochar-public-comment

Lee JW, Day DM (2013) Smokeless biomass pyrolysis for producing biofuels and biochar as a possible arsenal to control climate change. In: Lee JW (ed) Advanced biofuels and bioproducts, chap 3, vol 1. Springer, New York, pp 23-34

Lee JW, Kidder K, Evans BR, Paik S, Buchanan AC, Garten CT, Brown RC (2010a) Characterization of biochars produced from cornstovers for soil amendment and carbon sequestration. Environ Sci Technol 44:7970-7974

Lee JW, Hawkins B, Day DM, Reicosky DC (2010b) Sustainability: the capacity of smokeless biomass pyrolysis for energy production, global carbon capture and sequestration. Energy Environ Sci 3(11):1609-1812

Lee JW, Hawkins B, Li X, Day DM (2013) Biochar fertilizer for soil amendment and carbon sequestration. In: Lee JW (ed) Advanced biofuels and bioproducts, chap 6, vol 1. Springer, New York, pp 57-68

Lehmann J (2007) Commentary: a handful of carbon. Nature 447:143-144

Lehmann J, Gaunt J, Rondon M (2006) Bio-char sequestration in terrestrial ecosystems - a review. Mitig Adapt Strateg Glob Chang 11:403-427

Lehmannn J, Joseph S (2009) Biochar for environmental management: science and technology. Routledge, London, p 448

Liang B, Lehmann J, Solomon D, Kinyangi J, Grossman J, O'neill B, Skjemstad JO, Thies J, Luizao FJ, Petersen J, Neves EG (2006) Black carbon increases cation exchange capacity in soils. Soil Soc Am J 70:1719-1730

Manahan SE (1999) In: Environmental chemistry, 6th edn. CRC Press, Boca Raton, pp 80-480

Marris E (2006) Sequestration news feature: black is the new green. Nature 442:624-626

Novak JM, Busscher WJ (2013) Selection and use of designer biochars to improve characteristics of southeastern USA coastal plain degraded soils. In: Lee JW (ed) Advanced biofuels and bioproducts, chap 4. Springer, New York, pp 69-96

Novak JM, Cantrell KB, Watts DW, Busscher WJ, Johnson MG (2014) Designing relevant biochars as soil amendments using lignocellulosic-based and manure-based feedstocks. J Soils Sediments 14:330-343

Singh B, Lynne MM, Kokana RS, van Zwieten L, Butler G, Joseph S, Weatherley A, Kaudal BB, Regan A, Cattle J, Dijkstra F, Boersma M, Kimber S, Keith A, Esfandbod M (2014) Opportunities and constraints for biochar 
technology in Australian agriculture: looking beyond carbon sequestration. Soil Res 52:739-750

Singh R, Babua JN, Rabindra K, Srivastava P, Pardeep S, Akhilesh SR (2015) Multifaceted application of crop residue biochar as a tool for sustainable agriculture: an ecological perspective. Ecol Eng 77:324-347

Skjemstad JO, Gillman GP, Massis A, Spouncer LR (2008) The measurement of cation exchange capacity of organic matter fractions from soils using a modified compulsive exchange method. Commun Soil Sci Plant Anal 39(5):926-937

Socrates G (1980) Infrared characteristic group frequencies, 2nd edn. Wiley, Chichester, WS

Solomon D, Lehmann J, Thies J, Schafer T, Liang B, Kinyangi J, Neves E, Petersen J, Luizao F, Skjemstad J (2007) Molecular signature and sources of biochemical recalcitrance of organic $\mathrm{C}$ in Amazonian dark earths. Geochim Cosmochim Acta 71:2285-2298

Spokas KA, Baker JM, Reicosky DC (2010) Ethylene: potential key for biochar amendment impacts. Plant Soil 333:443-452

Srinivasan P, Sarmah AK, Smernik R, Das O, Farid M, Gao W (2015) A feasibility study of agricultural and sewage biomass as biochar, bioenergy and biocomposite feedstock: production, characterization and potential applications. Sci Total Environ 512:495-505
Topoliantz Stéphanie, Ponge Jean-François, Ballof Sylvain (2005) Manioc peel and charcoal: a potential organic amendment for sustainable soil fertility in the tropics. Biol Fertil Soils 41:15-21

Wang Y, Hu Y, Zhao X, Wang S, Xing G (2013) Comparisons of biochar properties from wood material and crop residues at different temperatures and residence times. Energy Fuels 27:5890-5899

Windeatt JH, Ross AB, Williams PT, Forster PM, Nahil MA, Singh S (2014) Characteristics of biochars from crop residues: potential for carbon sequestration and soil amendment. J Environ Manage 146:189-197

Zhang A, Cui L, Pan G, Li L, Hussain Q, Zhang X, Zheng J, Crowley D (2010) Effect of biochar amendment on yield and methane and nitrous oxide emissions from a rice paddy from Tai Lake plain, China. Agric Ecosyst Environ 139:469-475

Zhang QZ, Du ZL, Lou Y, He X (2015) A one-year short-term biochar application improved carbon accumulation in large macroaggregate fractions. Catena 127:26-31

Zhao X, Wang J, Wang S, Xing G (2014) Successive straw biochar application as a strategy to sequester carbon and improve fertility: a pot experiment with two rice/wheat rotations in paddy soil. Plant Soil 378:279-294

Zhao R, Neil C, Wu J (2015) Carbon mineralization following additions of fresh and aged biochar to an infertile soil. Catena 125:183-189

\section{Submit your manuscript to a SpringerOpen ${ }^{\odot}$ journal and benefit from:}

- Convenient online submission

- Rigorous peer review

- Immediate publication on acceptance

- Open access: articles freely available online

- High visibility within the field

- Retaining the copyright to your article

Submit your next manuscript at $\boldsymbol{\wedge}$ springeropen.com 